\title{
Transport as the Basis of Extending the Integration Processes of EurAsEC
}

\author{
Madiyarova Diana Makaevna, Abdrakhmanova Rauana Sembekovna \\ L.N. Gumilyov Eurasian National University, Astana, Republic of Kazakhstan
}

\begin{abstract}
Development of transport infrastructure one of the most urgent tasks for the states - members of the Eurasian Economic Community, the solution of which depends on the implementation of the priorities of the Community as integration in the field of bilateral trade, economic growth and employment and increasing the Eurasian transshipment. Development of transport routes will encourage the process of economic integration between the countries - members of the Eurasian Economic Community and the creation of the Common Economic Space. Implementation of a set of projects in 2020 will complete the formation of the Community transport routes. This will have a positive impact not only on the performance of transport systems, but also on the macro-economic indicators, due to the multiplicative effect from the implementation of projects.
\end{abstract}

Key words: Transport, integration processes, the Eurasian Economic Community, economic growth.

\section{Introduction}

Transport plays a dominant role in the socio-economic development of any country providing the conditions for economic growth, competitiveness of national economies and quality of life. Access to safe high quality and efficient transport system determines the efficiency of production and development, business and social issues.
Extension of international cooperation between the European Union (EU) and the Asia-Pacific Region (APR), the deepening of integration processes in the post-Soviet space and the increase in international trade requires an enabling environment for the smooth crossing of freight and passenger traffic related to ensuring interstate economic and cultural ties. [1, pp.421-426]

\section{The main results of the study}

Member states as the Commonwealth of Independent States (CIS) and the Eurasian Economic Community (EurAsEC), due to its geographical position, being located on a strategic route between East and West and their transport links are, in essence, the"bridge" between the European and Asian markets.

Meanwhile, for the EurAsEC member states - Belarus, Kazakhstan, Russia, Kyrgyzstan and Tajikistan - the volume of mutual trade and therefore freight which in recent years are characterized by rapid growth (by 2020, total volume of the transit of goods can reach 490 million tonnes, which is more than four times higher than in 2000). In total freight exchange within states - members of EurAsEC is dominated by Russia, Belarus and Kazakhstan (respectively 45.5\%, 34.9\% and 13.2\%). [2]

Export EurAsEC consists mainly of raw materials and large, in particular, engineering products, the viable solution of the problem the transportation of such products depends largely on the successful development of all their 
foreign trade. "Narrow space" of border crossings, long transshipment of transport terminals, non-compliance timetable transport vehicles are severely hampering their external trade and development of the integration process.

It should be noted that the transit potential of EurAsEC today is not fully claimed. Only half of the possible volume of traffic passing through the Community states. The main problem of the non-use of the transit potential is inability to attract transit traffic between two global goods-producing centers - the European Union and the Asia-Pacific region. The volume of trade between them in the next few years is to reach $\$ 1$ trillion. Only $1 \%$ of the total traffic between EU and APR at the moment is through the international transport corridors Communities, while billions of "transit" profit fall on maritime shipping companies. In other words, transit potential is not currently implemented. [3]

The study shows that in the space there is a number of problems as following.

With the Customs Union of Kazakhstan producers faced with non-compliance with the conditions prevailing in the market. The new union render difficult the problem solving, many factors, including economic. Thus, there is a high degree of physical and moral amortization significant part objective transport infrastructure and the rapid aging of the rolling stock of all types of transport. A very large part of the rolling stock discrepancy international environmental and operating needs. [4, p.43]

Taxation system of traffic transiting through the territory of Russia often serve as a barrier which was previously considered international and not subject to value added tax. With the introduction of the Customs Union of transit traffic, as well as transportation to Kazakhstan from
Russia were subject to VAT, which resulted in the increase in transport costs and, consequently, in value as the Kazakhstani goods and goods produced for domestic consumption in Kazakhstan from imported raw materials and components. [5]

The simplifying customs procedures has been equally important, since the Russian border the process of filling a large number of documents is carried out in a backup mode (specification of goods, by country of destination, date of loading and unloading, etc.) that dramatically increases the overall cost of funds and delivery time of goods. With intensive cargo traffic control bodies that are poorly aligned, do not have time to check the documents. Besides, there is a visual and excessive control, including goods from fair companies to operate without breaking customs regulations. If there is no possibility to store and analyze many documents almost all goods have to be visually controlled.

As the practice of management, development of transport links depends on the global environment, programs and projects of the freight traffic of the complex economic sectors of the Community and its foreign trade. A significant role in increasing the volume of mutual trade traffic between the EurAsEC is the elimination of borders and the harmonization of customs regulations.

Analysis of the situation in the market today can take a number of measures aimed at radically improving the integration process.

In general, integrated transport solutions are necessary in order to increase the effectiveness of the Union's foreign trade. Accordingly, the major problem is in this respect and the establishment of a unified concept of infrastructure networks, the development of which should come from international 
experience forming and operation of international transport corridors. [6, p.288]

For the development of transport routes it is important to establish international logistics centers within the Union. They will provide the rhythmic movement of goods on transportation systems, necessary for economic development, trade and implementation of transit potential, the creation of which will optimize the development and use of transport infrastructure and rolling stock vehicles, streamline collaboration and enhance the quality of service to all participants in the transport process, and integrate information and telecommunication systems of different types of transport.

Standard model logistics center (SMLC) as an element of international logistics center includes all areas and facilities necessary for the strategic objectives of the SMLC and its economic efficiency.

The scheme of arrangement expedient logistics centers determined governments Union, Kyrgyzstan and Tajikistan, according to national priorities and integration on the following criteria: the concentration of large cargo (trade, transit, inter-regional and regional) location at the crossroads of transport routes between themselves and with other major international routes, multimodality, the development of transport, warehousing and logistics infrastructure in the transport hub for its location close to transport links, the presence of free economic zones and distance from the borders of the Customs Union.

Arrangement of logistics centers on transport links provides reasonable distance between logistics facilities that improve the economic efficiency of transport, optimizing time to perform service procedures, to comply with requirements of work and leisure drivers.
In the development of the infrastructure of transportation routes by 2020 about \$ 96 billion will be invested whereof over $68 \%$ will be destined for the improvement of highways, $\$ 28$ billion (about 30\%) - the development of the railways. About $\$ 1$ billion will be invested in the improvement of logistics centers. The implementation of 23 major projects being worth $\$ 68$ billion requires the involvement of international financial institutions and development institutions, in particular the 11 projects of roads valued at \$ 43.2 billion, eight development projects of railways worth $\$ 24.3$ billion, and 4 of the creation of transport and logistics centers with a total value of $\$ 0.5$ billion.

The formation of transport routes one of the key elements to create a single transport space will be completed by 2020.

Calculations show that the implementation of a comprehensive plan will provide significant socio-economic benefits to all users of transportation services. This effect will be determined by:

-The increase in foreign trade cargo traffic by $60 \%$ by 2015 and 2.1 times by 2020;

- The increase in transit cargo through the territory of third countries of EurAsEC 2 times by 2015 and 3 times by 2020;

- The increase in the speed of delivery of cargo (7.5 miles per hour) and passengers (10.7 miles per hour);

- A decrease of $10.5 \%$ of unit costs for the transportation of passengers and goods by raising the technical level of the transport network and improve its use;

- A decrease of $40-60 \%$ in the number of dead and injured in traffic accidents on the roads within the EurAsEC transport routes;

- Reduction of the harmful effects of transport on the environment 
(reduction of specific emissions vehicles by $10-20 \%$, and the specific volume of greenhouse gas emissions by $5-15 \%)$;

- Reduction in fuel consumption by $10-15 \%$.

The development of transport routes are beyond the solving transport problems. They will have a positive impact on macroeconomic indicators, due multiplier effect of the project. This will be expressed by:

- Additional income budgets of all levels - EurAsEC from increased international transport, including transit (by 10-15\% from current levels);

- An increase in employment by $2-4 \%$ in transport, logistics sector and in related sectors of the economy and, ultimately, increases the standard of living;

- Production growth in traditional industries and agriculture, as well as in service industries (5 to $7 \%$ );

- Optimization of the transport component in the price of exports and imports (reducing it to the level of $10-14 \%$, depending on the type of cargo, the country and the mode of transport);

- Increase in cross-border trade (10-15\%);

- An increase in the number of business entities that have access to foreign markets (5-10\%);

- increase investment attractiveness of regions adjacent to transport routes;

- Multiplier effects in all sectors (development of the construction, the fuel and energy complex, transport engineering).

In general, the development of infrastructure of roads and railways, the listed transport routes can be considered as a contribution to the elimination of trade barriers and will encourage the process of economic integration between the member-states of the Eurasian
Economic Community and the creation of the Common Economic Space.

\section{References}

[1] D.Madiyarova, "Analysis of the current development of EurAsEC", Vestnik KazEU, vol. 2, pp.421-426, 2009.

[2] Official website of the Eurasian EconomicCommunity.Available:http:/ /www.evrazes.com/docs/statistics

[3] EurAsEC Transport Corridors: faster, cheaper, more. Industry Report, March 2009. Available: http://www.eabr.org/general/upload/d ocs/publication/analyticalreports/Full _report_5_2009.pdf

[4] I.Levitin, "The problem of forming a transport union and transit potential of EurAsEC”, Eurasian integration: economics, law and politics, vol.1, p.43, 2007.

[5] Customs Union - the prospects for integration.

Available: http://sovet-ts.ru/novosti/610/

[6] V.Galaburda, Integrated transport system, Moscow: Transport, 2001, p.288. 